\title{
Determination of tolerable dose of litchi fruit considering reported hypoglycin A and MCPG contents through biochemical and histopathological evaluations in mice
}

\author{
Jyoti Tripathi ${ }^{1}$, Nilantana Bandyopadhyay ${ }^{1}$, Sachin N. Hajare ${ }^{1}$, \\ Surbhi Wadhawan ${ }^{1}$, Haladhar Dev Sarma ${ }^{2}$ and Satyendra Gautam ${ }^{1,3, *}$ \\ ${ }^{1}$ Food Technology Division, Bhabha Atomic Research Centre, Mumbai 400 085, India \\ ${ }^{2}$ Radiation Biology and Health Science Division, Bhabha Atomic Research Centre, Mumbai 400 085, India \\ ${ }^{3}$ Homi Bhabha National Institute, Anushaktinagar, Mumbai 400 094, India
}

Litchi fruit has recently been reported to be associated with encephalopathy outbreaks in India due to presence of hypoglycaemic phytotoxins, hypoglycin A (HGA) and methylenecyclopropyl-glycine (MCPG). Therefore, a need was felt to determine safe tolerable dose of fruit based upon animal feeding studies. Swiss albino female mice (in each group, $n=6$ ) were fed in both starved and unstarved conditions with maximum possible quantity of litchi pulp within $10 \mathrm{~h}$ duration at $\mathbf{2 . 5} \mathrm{h}$ intervals (total quantity $\sim \mathbf{1 6} \mathrm{g}$ ). This did not result in hypoglycaemia, weight loss or changes in behaviour. Haematology profile, liver and kidney functions remain unchanged. Histopathological analysis of brain, liver and kidney too did not indicate any structural changes. From the reported range of above toxins in litchi pulp the quantity fed corresponds to the cumulative minimum concentration of 2.48 and $\sim 9.0 \mathrm{mg} / \mathrm{kg}$ body weight of mice for HGA and MCPG respectively, which is lesser than $L D_{50}$ values of these toxins, i.e. $90-100 \mathrm{mg} / \mathrm{kg}$ body weight reported in rat. Thus based upon equivalent dose-quantity conversion, approx. $3.9 \mathrm{~kg}$ of litchi pulp/day for an adult human (weighing $60 \mathrm{~kg}$ ) and $0.59-1.17 \mathrm{~kg}$ of pulp/day for children (1-5 years of age respectively) could be considered a safe quantity.

Keywords: Blood glucose, brain, haematology, kidney, liver, organ function tests.

THE litchi (Litchi chinensis) belongs to the family Sapindaceae. The fruit is non-climacteric and therefore harvested only upon ripening. Litchi is primarily grown in China, India, Taiwan, Thailand and Vietnam. The total global production of litchi fruit is estimated to be around 2.11 million tonnes. In India, Muzaffarpur district in Bihar, is the hub of litchi fruit cultivation with a production of 56,000 MT, where two varieties 'Shahi' and 'China' are quite common. These varieties are a good source of vitamin C (17-25 mg\%) and flavonoids. The fruit con-

*For correspondence. (e-mail: sgautam@barc.gov.in) tains $10-13 \mathrm{~g} \%$ of total sugar primarily in reducing form $^{1}$. Besides, litchi fruit has been reported to have several pharmacological potentials like hepatoprotective activity, as well as nootropic effect where litchi fruit extract was able to enhance cognitive functions in mice ${ }^{2-4}$.

In recent years between 2008 and 2014, Acute Encephalopathy Syndrome (AES) outbreaks have led to nearly 6000 deaths in India and Bangladesh. These AES outbreaks have long been called mystery disease as no definite clinical diagnosis had been made ${ }^{5}$. In India, particularly in Uttar Pradesh and Bihar, most of the cases occurred during May-June and October-November ${ }^{6}$. Previous studies in different laboratories had reported unhygienic conditions to be linked with the AES, some specialists have suggested that high temperature during summer leading to sunstroke may be a possible reason of $\mathrm{AES}^{7,8}$. Few other authors have reported viral etiology pertaining to the AES outbreak, which may be caused by bats infecting litchi fruits ${ }^{9,10}$. Similar outbreaks have been reported in other Asian countries like Bangladesh, where the AES has been linked with the exposure to the routinely used pesticides in litchi orchard ${ }^{11}$. Some of these studies co-related it with litchi consumption as the season of AES outbreaks well coincided with litchi harvest period in the dry hot months of late May and early June when average temperature is above $40^{\circ} \mathrm{C}$. A report by John and colleagues linked the AES outbreak with litchi consumption suspecting the cause as hypoglycaemic phytotoxins, hypoglycin A (HGA) and methylenecyclopropyl-glycine $(\mathrm{MCPG})^{12}$. However, recently a report showed that these phytotoxins (HGA and MCPG) are present in litchi at a very low concentration of $12.4-152 \mu \mathrm{g} / \mathrm{g}$ and $44.9-$ $220 \mu \mathrm{g} / \mathrm{g}$ respectively ${ }^{13}$. Apart from litchi, ackee (Blighia sapida) is another popular tropical fruit belonging to the same family. Consumption of unripe stage of this fruit had long been reported to cause 'Jamaican vomiting sickness' owing to the presence of hypoglycin A, a hypoglycaemic toxin, at a very high concentration of 5.1$9.2 \mathrm{mg} / \mathrm{g}$ in the unripe fruit ${ }^{14,15}$. The toxicity of MCPG 
has already been thoroughly studied by other group of researchers where administration of $100 \mathrm{mg}$ of $\mathrm{MCPG} / \mathrm{kg}$ body weight in rats, caused a $72 \%$ decrease in plasma glucose concentration after $4 \mathrm{~h}$ (ref. 16). Similarly, hypoglycaemic effect of HGA has also been studied in rat where $100 \mathrm{mg} \mathrm{HGA} / \mathrm{kg}$ body wt was able to decrease blood glucose up to $2-3 \mathrm{mM}$ after $12-15 \mathrm{~h}$ of administration $^{17}$. The oral $\mathrm{LD}_{50}$ values of HGA have been reported to be $98 \mathrm{mg} / \mathrm{kg}$ body weight for rats ${ }^{18}$. The Food and Drug Administration of the United States restricts the limit of hypoglycin A to $100 \mathrm{mg} / \mathrm{kg}$ weight of fruit in the canned aril of ackee fruits ${ }^{19}$. As there are claims for the notion that AES outbreaks are probably caused by toxins in litchi, it is important to determine a safe tolerable dose of litchi, as the fruit is liked and consumed by a large population worldwide.

Therefore, the present study was designed to assess the acute toxicity of litchi in Swiss female mice, feeding them with the most popular litchi variety locally called as 'China'. The exclusive feeding was limited to the daily calorific requirement of mice $(18 \mathrm{kcal}$ metabolizable energy/day). However, as some of the studies have shown that starving or absence of evening meal potentiates the effect of the toxins in litchi, the study was planned with both starved and unstarved conditions for deciding a safe tolerable dose. During the feeding, the behaviour and weight of animals were observed and the blood glucose was monitored, including various other parameters of haematology as well as liver and kidney function tests. The histopathological analysis of brain, liver and kidney was also performed. The findings were further extrapolated to determine the tolerable dose in human system based upon equivalent dose conversion.

\section{Material and methods}

\section{Animals and ethical approval}

For animal studies approval was obtained from Institutional Animal Ethics Committee (IAEC), Bhabha Atomic Research Centre, Mumbai (Regn No. 106/GO/RBi/S/99/ CPCSEA). Female Swiss albino mice, 5-6 weeks old, weighing approximately 18-22 g, bred at animal house facility of Bhabha Atomic Research Centre (BARC) were used for the study. The animals were maintained under standard conditions of temperature and humidity (28 \pm $\left.2{ }^{\circ} \mathrm{C} ; 60-70 \% \mathrm{RH}\right)$ and all the experiments were conducted as per the guidelines issued by the IAEC, BARC. Animals were provided with food and water ad libitum. Three animals were housed in a polypropylene cage containing sterile corn cob as bedding.

\section{Litchi procurement and extract preparation}

The litchi cv. 'China' was procured from Muzaffarpur, India. The $5 \mathrm{~kg}$ fruit sample were peeled off and deseeded. The fruit pulp was homogenized in a blender and centrifuged at $1000 \mathrm{~g}$ for $10 \mathrm{~min}$. The supernatant was collected, lyophilized and reconstituted to concentrate the juice to six times $(6 \times)$, and was fed to mice using oral gavage. Parallelly, the pellet containing the remaining solid fibre was also dried and served to mice for consumption in the form of food pellet. The total volume of the feed/animal was calculated according to the energy requirement of the mice in terms of calorie intake (18 kcal metabolizable energy/day). The total feed volume was distributed into four feeds within $10 \mathrm{~h}$ duration at $2.5 \mathrm{~h}$ intervals which was equivalent to $16 \mathrm{~g}$ litchi pulp for each mouse.

\section{Litchi administration}

The mice $(n=18)$ were randomly divided into three groups of six animals each. The first control group mice were provided with food and water ad libitum, the second unstarved group (USFL; unstarved fed with litchi) was fed with litchi juice using oral gavage and the remaining solid fibre, along with ad libitum food and water, and the third starved group (SFL; starved fed with litchi) was kept without food for $6 \mathrm{~h}$ and then were fed only with the litchi juice and the remaining solid fibre with normal water intake.

\section{Blood glucose analysis}

After litchi administration, the next morning all the groups of mice were sacrificed and blood was collected from the heart for glucose analysis. The blood glucose analysis was performed using glucometer reading based on glucose oxidase biosensor (OneTouch, Life Scan, Inc, Europe $)^{20}$. Similarly, another group of mice containing 52 animals, was fed with litchi only and during the feeding, the blood glucose was monitored till $56 \mathrm{~h}$ at different time points. The tail vein was punctured with minimum distress to the mice, for collection of the blood required for analysis.

\section{Haematological analysis}

The blood from each mice was individually collected in sodium heparin-coated tubes (4 ml capacity) and gently shaken to avoid microclotting. The samples were immediately processed. Each blood sample was individually analysed using Mindray haematology analyser and reagents (Shenzhen Mindray Bio-Medical Electronics Co. $\mathrm{Ltd}$, China) for the routine haematology parameters.

\section{Biochemical analysis}

The blood sample was centrifuged at $3000 \mathrm{~g}$ for $10 \mathrm{~min}$ to obtain the serum. The serum was used for estimating the 
biochemical parameters pertaining to the liver and kidney functions, using EM-200 Automated Random Access Clinical Chemistry Analyzer (ERBA Diagnostics Mannheim, Germany). All parameters were studied based on colorimetric analysis using Merck kits (Darmstadt, Germany).

Liver function test: Bilirubin assay kit measures the total and conjugated bilirubin based on Jendrassik-Grof method. The bilirubin in the sample reacts with diazotized sulphanilic acid which results in a colorimetric product with absorbance at $\lambda_{\max } 530 \mathrm{~nm}$ (ref. 21).

Aspartate aminotransferase (AST) activity involves the transfer of an amino group from aspartate to $\alpha$-ketoglutarate which results in formation of oxaloacetate and glutamate. This gives a colorimetric $\left(\lambda_{\max } 450 \mathrm{~nm}\right)$ product proportional to the AST enzymatic activity present ${ }^{22}$.

Alanine aminotransferase (ALT) enzyme, also known as serum glutamic-pyruvic transaminase (SGPT), catalyses the reversible transfer of an amino group from alanine to $\alpha$-ketoglutarate, generating pyruvate and glutamate. The pyruvate generated results in a colorimetric $\left(\lambda_{\max }\right.$ $570 \mathrm{~nm}$ ) product by a coupled enzyme assay ${ }^{22}$.

Alkaline phosphatase (ALP) catalyses the hydrolysis of phosphate esters, the kit uses p-nitrophenyl phosphate (pNPP) as the phosphatase substrate which turns yellow $\left(\lambda_{\max } 405 \mathrm{~nm}\right)$ when dephosphorylated by $\mathrm{ALP}^{23}$.

Kidney function test: Creatinine assay kit method utilizes the reaction of picrate with creatinine which forms a red coloured complex. This complex absorbs at $\lambda_{\max }$ of $510 \mathrm{~nm}$ (ref. 24).

The blood urea nitrogen content measuring kit uses a chromogenic reagent that forms a coloured complex $\left(\lambda_{\max }\right.$ $520 \mathrm{~nm})($ ref. 25).

The electrolytes $(\mathrm{Na}, \mathrm{K}, \mathrm{Cl})$ were analysed using the Ion Selective Electrode (ISE) of EM-200 Clinical Chemistry Analyzer (ERBA Diagnostics Mannheim, Germany).

Calcium assay kit utilizes the reaction between calcium ions and o-cresolphthalein which forms a chromogenic complex and measured at $\lambda_{\max } 575 \mathrm{~nm}$ (ref. 26). Similarly, phosphorus in blood can react with ammonium molybdate and ferrous sulphate, where the product is measured at $620 \mathrm{~nm}$ (ref. 27).

\section{Histopathological analysis}

The organs brain, kidney and liver were excised and tissue were fixed in $10 \%$ formalin for histopathological preparations. The samples were paraffin embedded and $3 \mu \mathrm{m}$ thick sections were cut using microtome. These sections were stained with haematoxylin and eosin (H\&E) stain and assessed for histopathological variation using microscopic examination.

\section{Statistical analysis}

Results are shown as mean \pm standard deviation of readings for each group of mice for specific parameter and time point of analysis. $P$ value (level of significance) was calculated using one-way analysis of variance (ANOVA) using Prism version 6.05 for Windows (GraphPad Software, San Diego, CA). $P<0.05$ was considered as statistically significant.

\section{Results and discussion}

The traditional Indian and Chinese medicine has recorded litchi to contain several health protective properties including antioxidant, anti-cancer, hepatoprotective, antibacterial, antimutagenic, anti-pyretic, anti-inflammatory and antiviral properties ${ }^{28}$. However, it was until recently when acute encephalopathy outbreaks in India were linked with this fruit, which led to doubt among the consumers about its safety ${ }^{12}$. The present results show that feeding of litchi to mice at the maximum possible dose, did not show any mortality in any group of mice. We also further checked for any other observable signs of toxicity.

\section{No mortality, behavioural change or any toxicity observed}

The two groups of mice, the USFL group which were on a diet of litchi juice during the day time, while at normal ad libitum diet at night and the SFL group which were starved for $6 \mathrm{~h}$, then were maintained strictly on a diet of only litchi for $24 \mathrm{~h}$ supplemented with normal water, did not show any change in behavioural trait compared to the untreated mice (data not shown). The body weight is an important factor to analyse the toxic effect of any dietary component, and $10 \%$ or more reduction in body weight is considered to be toxic. The litchi pulp fed to mice up till a stretch of $56 \mathrm{~h}$ did not result in any decrease in body weight ascertaining the toxicological safety of litchi (Supplementary Figure 1).

\section{No change in blood glucose levels}

As the delayed hypoglycaemia is the major symptom of AES in children, we measured the blood glucose levels of the different groups of mice. The normal blood glucose level of the female Swiss albino mice, reared at the animal house facility and fed ad libitum was found to be $176 \pm 28.3 \mathrm{mg} / \mathrm{dl}$ in the morning which varied in the range $130-200 \mathrm{mg} / \mathrm{dl}$ throughout the day. The USFL group of mice did not show any significant difference in the blood glucose level and was similar to the control mice (Table 1). The blood glucose level in the SFL group 


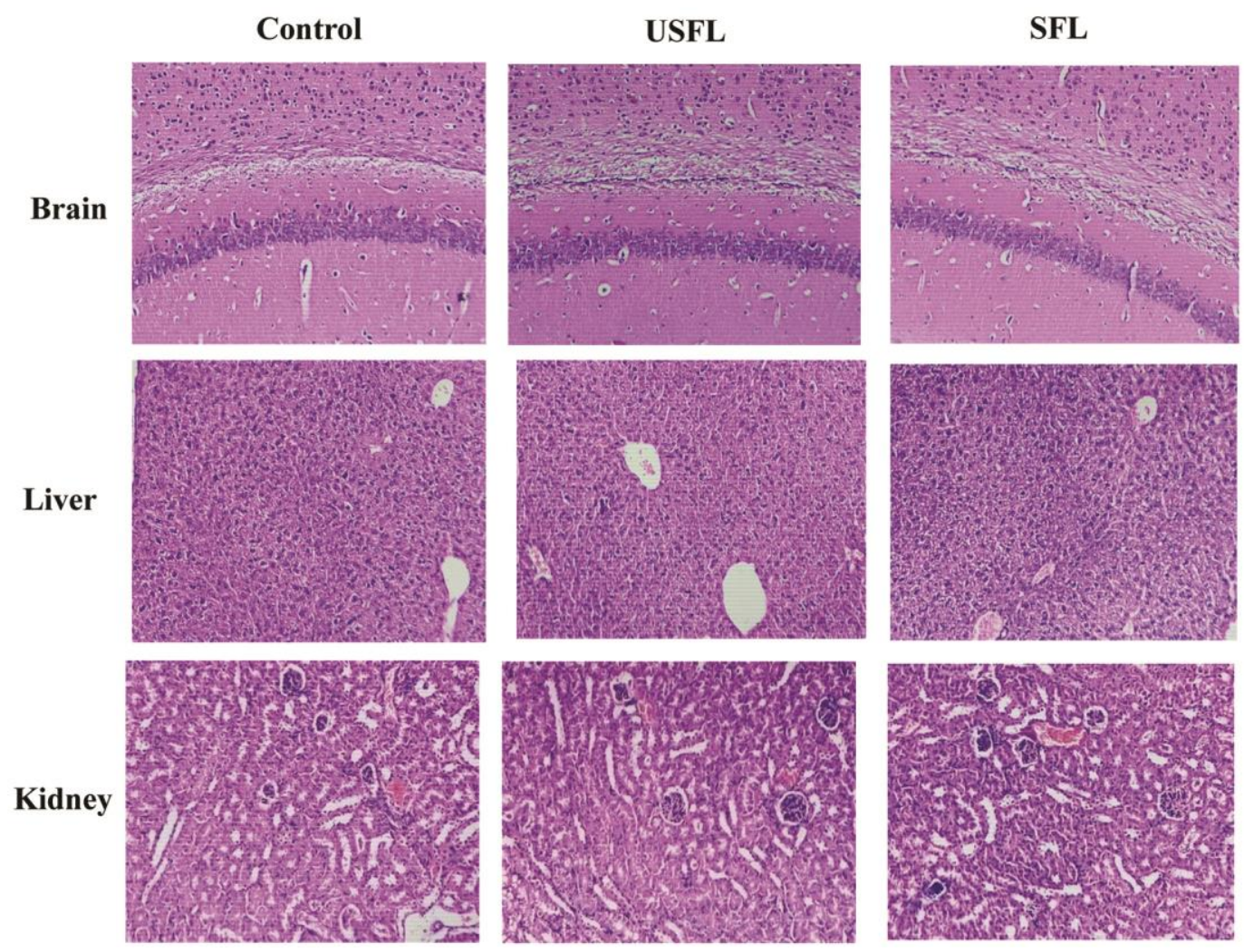

Figure 1. Photomicrograph showing histopathological sections of brain, liver and kidney.

Table 1. Blood glucose level of mice at different feeding conditions

\begin{tabular}{lc}
\hline & Glucose $(\mathrm{mg} / \mathrm{dl})$ \\
\hline Control & $176 \pm 28^{\mathrm{a}}$ \\
USFL & $206 \pm 59^{\mathrm{a}}$ \\
SFL & $234 \pm 29^{\mathrm{a}}$ \\
\hline
\end{tabular}

The measurements were taken in next morning after feeding the mice at the evening. Control represents mice with ad libitum food and water; USFL denotes unstarved mice fed with litchi and then ad libitum food and water and SFL is the group of mice which was starved and fed only with litchi with ad libitum water. Different letters as superscript across the column indicate significant differences in the mean value at $P<0.05$.

of mice was also in the similar range. As it is apparent that the mice showed no signs of hypoglycaemia, we decided to evaluate the effect of acute administration of litchi pulp where mice were kept exclusively on a litchi diet along with normal water intake for $56 \mathrm{~h}$. The blood glucose level was monitored intermittently as given in Table 2. In these mice the glucose level ranged between 126 and $220 \mathrm{mg} / \mathrm{dl}$ and no abnormal variation in glucose level (hypo or hyperglycaemia) was observed during the period of $56 \mathrm{~h}$ of litchi feeding, indicating that litchi consumption had no effect on the glycaemic condition of mice, irrespective of the starvation.

\section{Haematological parameters showed no variation}

To further evaluate the toxicity of litchi in mice, the haematology parameters of blood were analysed. Analysis of blood parameters is very much relevant to risk evaluation due to any toxicants and therefore changes in the haematological system in animal model systems have reasonable possibility for human toxicity too. The haematological analysis showed that the haemoglobin $(\mathrm{Hb})$ content of control mice was $13.8 \pm 0.5 \mathrm{gm} \%$. The USFL and SFL group showed no significant variation from this normal value (Table 3 ). The red blood cell (RBC), white blood cell (WBC) and platelet (PLT) counts of control mice group were found to be $6.7 \pm 0.4 \times$ $10^{6} / \mathrm{cmm}, 3.3 \pm 1.5 \times 10^{3} / \mathrm{cmm}$ and $94.8 \pm 4.6 \times 10^{5} / \mathrm{cmm}$ respectively, which varied within normal range among the test groups (USFL and SFL). The RBC count and haemoglobin which is the primary intracellular protein of RBCs were normal in litchi-fed animals with no indication of anaemia or any other pathological conditions. The normal platelet and WBC differential count suggested no sign of infection or inflammation in any group of mice. The other RBC indices like packed cell volume (PCV), mean corpuscular volume (MCV), mean corpuscular 
haemoglobin $(\mathrm{MCH})$ and mean corpuscular haemoglobin concentration (MCHC); used to describe the concentration of haemoglobin and further to suggest the restoration of oxygen-carrying capacity of the blood; were found to be $33.5 \pm 1.8 \%, \quad 49.9 \pm 1.1$ femtolitre, $20.3 \pm 1.3$ picogram and $40.7 \pm 2.0 \mathrm{gm} / \mathrm{dl}$ respectively, which were within normal range in control and test groups (Table 3), indicating no significant effect of litchi on the size and $\mathrm{Hb}$ content of RBCs. The differential count of each cell type of white blood cell, i.e. neutrophil $(\mathrm{N})$, eosinophil (E), lymphocyte (L) and monocyte (M) was found to be $28.8 \pm 4.6 \%, 0.8 \pm 1.0 \%, 71.4 \pm 8.1 \%$, and $1.4 \pm 0.5 \%$

Table 2. Blood glucose analysis of mice fed only with litchi up till different time intervals

\begin{tabular}{lc}
\hline Time point $(\mathrm{h})$ & Blood glucose $(\mathrm{mg} / \mathrm{dl})$ \\
\hline 0 & $126 \pm 12^{\mathrm{a}}$ \\
0.25 & $191 \pm 56^{\mathrm{a}}$ \\
0.5 & $147 \pm 23^{\mathrm{a}}$ \\
0.75 & $175 \pm 42^{\mathrm{a}}$ \\
1 & $220 \pm 53^{\mathrm{a}}$ \\
1.5 & $150 \pm 30^{\mathrm{a}}$ \\
2 & $167 \pm 31^{\mathrm{a}}$ \\
2.5 & $152 \pm 25^{\mathrm{a}}$ \\
3 & $127 \pm 5^{\mathrm{a}}$ \\
8 & $171 \pm 35^{\mathrm{a}}$ \\
16 & $135 \pm 20^{\mathrm{a}}$ \\
24 & $146 \pm 22^{\mathrm{a}}$ \\
36 & $125 \pm 8^{\mathrm{a}}$ \\
48 & $189 \pm 35^{\mathrm{a}}$ \\
56 & $139 \pm 32^{\mathrm{a}}$ \\
\hline
\end{tabular}

Different letters as superscript across the column indicate significant differences in the mean value at $P<0.05$.

Table 3. Haematology data of mice fed with litchi at different conditions

\begin{tabular}{lrrr}
\hline & Control & USFL & \multicolumn{1}{c}{ SFL } \\
\hline $\mathrm{Hb}(\mathrm{g} \%)$ & $13.8 \pm 0.5^{\mathrm{a}}$ & $14.1 \pm 0.7^{\mathrm{a}}$ & $15.3 \pm 0.9^{\mathrm{a}}$ \\
$\mathrm{RBC}\left(\times 10^{6} / \mathrm{cmm}\right)$ & $6.7 \pm 0.4^{\mathrm{a}}$ & $7.0 \pm 0.2^{\mathrm{a}}$ & $7.9 \pm 0.4^{\mathrm{b}}$ \\
$\mathrm{WBC}\left(\times 10^{3} / \mathrm{cmm}\right)$ & $3.3 \pm 1.5^{\mathrm{a}}$ & $2.2 \pm 0.4^{\mathrm{a}}$ & $2.8 \pm 0.5^{\mathrm{a}}$ \\
$\mathrm{PLT}\left(\times 10^{5} / \mathrm{cmm}\right)$ & $94.8 \pm 4.6^{\mathrm{a}}$ & $111.5 \pm 24.6^{\mathrm{a}}$ & $108.0 \pm 21.2^{\mathrm{a}}$ \\
$\mathrm{PCV}(\%)$ & $33.5 \pm 1.8^{\mathrm{a}}$ & $34.5 \pm 1.4^{\mathrm{a}}$ & $38.9 \pm 2.1^{\mathrm{b}}$ \\
$\mathrm{MCV}(\mathrm{fl})$ & $49.9 \pm 1.1^{\mathrm{a}}$ & $49.2 \pm 1.5^{\mathrm{a}}$ & $48.7 \pm 0.3^{\mathrm{a}}$ \\
$\mathrm{MCH}(\mathrm{pg})$ & $20.3 \pm 1.3^{\mathrm{a}}$ & $20.0 \pm 0.7^{\mathrm{a}}$ & $19.8 \pm 0.5^{\mathrm{a}}$ \\
$\mathrm{MCHC}(\mathrm{gm} / \mathrm{dl})$ & $40.7 \pm 2.0^{\mathrm{a}}$ & $40.8 \pm 0.4^{\mathrm{a}}$ & $40.6 \pm 0.8^{\mathrm{a}}$ \\
$\mathrm{N}(\%)$ & $28.8 \pm 4.6^{\mathrm{a}}$ & $27.3 \pm 5.1^{\mathrm{a}}$ & $28.7 \pm 5.4^{\mathrm{a}}$ \\
$\mathrm{E}(\%)$ & $0.8 \pm 1.0^{\mathrm{a}}$ & $1.0 \pm 1.0^{\mathrm{a}}$ & $1.6 \pm 0.5^{\mathrm{a}}$ \\
$\mathrm{L}(\%)$ & $71.4 \pm 8.1^{\mathrm{a}}$ & $72.3 \pm 7.4^{\mathrm{a}}$ & $68.2 \pm 5.8^{\mathrm{a}}$ \\
$\mathrm{M}(\%)$ & $1.4 \pm 0.5^{\mathrm{a}}$ & $1.3 \pm 0.5^{\mathrm{a}}$ & $1.0 \pm 0.0^{\mathrm{a}}$ \\
\hline
\end{tabular}

Hb, Haemoglobin; RBC, red blood cells; WBC, white blood cells; PLT, platelets; PCV, packed cell volume; MCV, mean corpuscular volume; $\mathrm{MCH}$, mean corpuscular haemoglobin; MCHC, mean corpuscular haemoglobin concentration; N, neutrophil; E, eosinophil; L, lymphocyte; $\mathrm{M}$, monocyte. Different letters as superscript across the row indicate significant differences in the mean value at $P<0.05$. respectively, which was within normal range in all the three groups, thus ensuring the healthy condition of the mice.

\section{LFT indicated proper liver functioning in all groups of mice}

As any dietary toxic component affects the vital organ function, it was necessary to assess the liver and kidney functions to evaluate the possibility of litchi toxicity. When liver cell membrane is damaged, many enzymes normally located in the cytosol are released into the blood stream. Measurements of the activities of serum marker enzymes like alanine transaminase (ALT), aspartate transaminase (AST) and alkaline phosphatase (ALP) have provided an important tool for the assessment of liver functions ${ }^{29}$. So, the liver function tests which measure the specific enzymes and protein in blood were analysed to evaluate the proper functioning of liver of mice fed with acute dose of litchi. The total bilirubin level [BILLI (T)] which contains the conjugated and unconjugated bilirubin was found to be $0.3 \pm 0.1 \mathrm{mg} / \mathrm{dl}$ and the conjugated (direct) bilirubin [BILLI (D)] was measured to be $0.2 \pm 0.1 \mathrm{mg} / \mathrm{dl}$. However, these levels remained unchanged between the control and test groups (Table 4). Bilirubin which is a breakdown product of RBCs and is normally processed by liver, increases in blood during the condition of liver dysfunction, however in the present study, the total bilirubin level, both conjugated and unconjugated, was found to be normal in mice fed with litchi compared to control mice. The liver-specific enzyme activities like AST, ALT and ALP were determined to be $368.8 \pm 105.9 \mathrm{IU} / 1,54.3 \pm 12.3 \mathrm{IU} / 1$ and $623.0 \pm$ $138.8 \mathrm{IU} / 1$ respectively. The enzyme activity varied insignificantly among the test group with respect to that of control which shows a healthy liver function. Liver is the main source of serum protein and also the only site of synthesis of albumin. Any significant change in protein and albumin level in blood indicates liver dysfunction which impairs protein synthesis. The total protein was determined to be $5.9 \pm 0.2 \mathrm{~g} / \mathrm{dl}$ where albumin and globulin were the major constituents at a level of $3.1 \pm 0.4$ and $2.8 \pm 0.5 \mathrm{~g} / \mathrm{dl}$ respectively. The level of these proteins did not change significantly in all the three groups indicating no liver dysfunction (Table 4). Our results indicate that litchi consumption has no adverse effect on liver function in mice. Previous studies from India too have shown that extracts of Litchi chinensis fruit and leaf offered potential hepatoprotection against carbon tetrachloride and paracetamol induced liver damage $e^{2,30,31}$.

\section{Normal kidney function in all groups of mice}

The kidney is one of the vital organs in the body which helps in excreting the waste of the body in the form of 
Table 4. Liver function test

\begin{tabular}{lccc}
\hline & Control & USFL & SFL \\
\hline BILLI (T) (mg/dl) & $0.3 \pm 0.1^{\mathrm{a}}$ & $0.4 \pm 0.1^{\mathrm{a}}$ & $0.4 \pm 0.1^{\mathrm{a}}$ \\
BILLI (D) (mg/dl) & $0.2 \pm 0.1^{\mathrm{a}}$ & $0.2 \pm 0.1^{\mathrm{a}}$ & $0.2 \pm 0.0^{\mathrm{a}}$ \\
AST (IU/l) & $369 \pm 106^{\mathrm{a}}$ & $285 \pm 153^{\mathrm{a}}$ & $302 \pm 123^{\mathrm{a}}$ \\
ALT (IU/l) & $54.3 \pm 12.3^{\mathrm{a}}$ & $58.7 \pm 13.7^{\mathrm{a}}$ & $61.7 \pm 12.7^{\mathrm{a}}$ \\
ALP (IU/l) & $623 \pm 139^{\mathrm{a}}$ & $579 \pm 186^{\mathrm{a}}$ & $675 \pm 289^{\mathrm{a}}$ \\
Total PRO (g/dl) & $5.9 \pm 0.2^{\mathrm{a}}$ & $5.9 \pm 0.4^{\mathrm{a}}$ & $5.6 \pm 0.4^{\mathrm{a}}$ \\
ALB (g/dl) & $3.1 \pm 0.4^{\mathrm{a}}$ & $3.3 \pm 0.3^{\mathrm{a}}$ & $3.1 \pm 0.6^{\mathrm{a}}$ \\
GLB (g/dl) & $2.8 \pm 0.5^{\mathrm{a}}$ & $2.6 \pm 0.6^{\mathrm{a}}$ & $2.6 \pm 0.3^{\mathrm{a}}$ \\
\hline
\end{tabular}

BILLI (T), Total bilirubin; BILLI (D), direct bilirubin; AST, aspartate transaminase; ALT, alanine transaminase; ALP, alkaline phosphatase; Total PRO, total protein; ALB, albumin; GLB, globulin. Different letters as superscript across the row indicate significant differences in the mean value at $P<0.05$.

Table 5. Kidney function test

\begin{tabular}{lrrr}
\hline & \multicolumn{1}{c}{ Control } & \multicolumn{1}{c}{ USFL } & \multicolumn{1}{c}{ SFL } \\
\hline BUN (mg/dl) & $17.8 \pm 4.9^{\mathrm{a}}$ & $19.5 \pm 2.6^{\mathrm{a}}$ & $17.5 \pm 2.5^{\mathrm{a}}$ \\
CREAT (mg/dl) & $0.5 \pm 0.1^{\mathrm{a}}$ & $0.5 \pm 0.1^{\mathrm{a}}$ & $0.5 \pm 0.2^{\mathrm{a}}$ \\
Electrolytes (mEq/l) & & & \\
$\mathrm{Na}$ & $140.9 \pm 2.2^{\mathrm{a}}$ & $141.0 \pm 1.8^{\mathrm{a}}$ & $141.2 \pm 4.6^{\mathrm{a}}$ \\
$\mathrm{K}$ & $4.1 \pm 0.2^{\mathrm{a}}$ & $4.2 \pm 0.3^{\mathrm{a}}$ & $4.2 \pm 0.4^{\mathrm{a}}$ \\
$\mathrm{Cl}$ & $100.3 \pm 1.1^{\mathrm{a}}$ & $101.1 \pm 2.7^{\mathrm{a}}$ & $100.8 \pm 2.5^{\mathrm{a}}$ \\
Calcium (mg/dl) & $8.8 \pm 0.2^{\mathrm{a}}$ & $8.6 \pm 0.6^{\mathrm{a}}$ & $8.5 \pm 0.5^{\mathrm{a}}$ \\
Phosphorus (mg/dl) & $4.2 \pm 0.5^{\mathrm{a}}$ & $4.1 \pm 0.3^{\mathrm{a}}$ & $4.1 \pm 0.3^{\mathrm{a}}$ \\
\hline
\end{tabular}

BUN, Blood urea nitrogen; CREAT, creatinine; Na, sodium; K, potassium; $\mathrm{Cl}$, chloride. Different letters as superscript across the row indicate significant differences in the mean value at $P<0.05$.

urine which comprises creatinine and blood urea nitrogen (BUN). Urea is the principal nitrogenous waste product of metabolism and is generated from protein breakdown. Urea and creatinine content in blood are considered as a suitable prognostic indicator of renal dysfunction and kidney failure due to any toxic compounds as they provide essential information about renal function, particularly excretion and homeostasis. The renal function biomarkers, BUN and creatinine (CREAT) contents, were found to be $17.8 \pm 4.9 \mathrm{mg} / \mathrm{dl}$ and $0.5 \pm 0.1 \mathrm{mg} / \mathrm{dl} \mathrm{respec}-$ tively, in the untreated mice. The BUN and CREAT contents did not change significantly in the group of mice fed with litchi irrespective of the starved condition indicating proper kidney function (Table 5). The electrolytes in blood are measured to assess renal (kidney), endocrine (glandular) and acid-base function and are components of both renal function and comprehensive metabolic biochemical profiles ${ }^{32}$. The blood electrolytes like sodium $(\mathrm{Na})$, potassium $(\mathrm{K})$ and chloride $(\mathrm{Cl})$ were found to remain almost unchanged in all the three groups. The calcium and phosphorus contents in blood were $8.8 \pm 0.2$ and $4.2 \pm 0.5 \mathrm{mg} / \mathrm{dl}$ respectively, which did not vary among the litchi fed and control groups, showing efficient functioning of kidney in all groups of mice. In this study the absence of significant differences in these parameters in- dicated that litchi pulp has no harmful effect on kidney and is not nephrotoxic.

\section{Histopathological analysis showed no treatment related changes}

The functional studies also need to be coupled with the appropriate histological studies for further validation. A1terations observed in the tissue metabolism are very often due to the dysfunction at the cellular level and therefore such studies would help in assessing the side effects caused due to the ingestion of phytotoxins. The histological analysis of the major organs of the mice, i.e. brain, liver and kidney showed no treatment-related changes in any part of these organs (Figure 1). The brain histological sections showed normal neuronal cells with no vascular or inflammatory changes after administration of litchi in mice (Figure $1 a-c$ ). Light microscopic examination of the cross section of liver tissues revealed normal architecture of hepatocytes with no alteration in nuclear or cytoplasmic structure in all the groups of mice (Figure $1 d-f$ ). The blood vessels were intact with no signs of haemorrhage or inflammation. Similarly, the section from the kidney showed compact arrangement of cells with intact 
renal corpuscle and kidney tubules indicative of a normal structural integrity (Figure $1 g-i$ ). Not only the microscopic structure but also the external morphology can be easily affected due to the treatment with a particular toxicant. Morphologically brain, liver and kidney of treated group and control group animals showed their typical structure with no alteration in outer surface. Besides, no changes were observed in the size of the organs as well. This corroborated the safety data obtained through physiological, biochemical and haematological parameters analysis upon litchi administration in mice. This rules out the possibility of development of brain dysfunction or encephalopathy.

\section{Determination of safe dose of litchi}

As the current findings ruled out the toxicity of litchi at the maximum possible quantity in the mice model system, it is important to determine the safe dose of litchi for humans too. Previous reports have shown that in rats HGA has $\mathrm{LD}_{50}$ dose of $98 \mathrm{mg} / \mathrm{kg} \mathrm{BW}$, while MCPG at a dose of $100 \mathrm{mg} / \mathrm{kg}$ BW causes $72 \%$ reduction in plasma blood glucose after $4 \mathrm{~h}$ (refs 16, 18). Conceding the reports from various authors that litchi arils contain HGA (12.4-152 $\mu \mathrm{g} / \mathrm{g}$ dry weight) and MCPG (44.9-220 $\mu \mathrm{g} / \mathrm{g}$ dry weight), during our experiment a cumulative minimum of $2.48 \mathrm{mg} / \mathrm{kg}$ body weight (BW)/day HGA and $\sim 9.0 \mathrm{mg} / \mathrm{kg} \mathrm{BW} /$ day MCPG was given to starved and unstarved mice in the form of equivalent litchi concentrate which corresponds to $0.2 \mathrm{mg}$ HGA and $0.73 \mathrm{mg}$ MCPG/ $\mathrm{kg}$ body weight/day in human system according to the animal equivalent dose conversion based upon body surface area (Supplementary Table 1$)^{33}$. This corresponds to $65.1 \mathrm{~g}$ fresh litchi pulp/kg BW/day (Supplementary Table 1). Based upon the results and subsequent animal equivalent dose conversion, the amount of litchi that an average human being weighing $60 \mathrm{~kg}$ can consume safely is $3.9 \mathrm{~kg}$ fresh pulp per day and children of age between 1 and 5 years can safely consume $0.59-1.17 \mathrm{~kg}$ fresh pulp per day (Supplementary Table 1), which is much more than the usually consumed quantity of litchi pulp per day by an individual. The findings thus indicate that to get some toxic effect of litchi, its consumption is required at possibly much higher level.

\section{Conclusion}

The biochemical and histopathological evaluation of litchi-fed mice at the maximum possible quantity showed no signs of hypoglycaemia or any toxicity even in the starved condition, indicating the amount of litchi fed to be safe for human consumption which corresponds to $65.1 \mathrm{~g}$ fresh litchi pulp/kg BW/day equivalent to $\sim 3.9 \mathrm{~kg}$ fresh litchi pulp per day for human adult weighing $60 \mathrm{~kg}$ and $0.59-1.17 \mathrm{~kg}$ fresh pulp per day for children of age between 1 and 5 years. As pulp to fruit ratio in case of litchi is almost $1: 2$, all these tolerable values get doubled (i.e. $7.8 \mathrm{~kg}$ for adult and 1.17 to $2.34 \mathrm{~kg}$ for children) while considering litchi fruit weight. Based upon the tolerable quantity established here, the current findings thus indicate safety of litchi fruit for consumption of human adults as well as children.

Conflict of interest statement. The authors declare that they have no conflict of interest.

1. Hajare, S. N. et al., Quality profile of litchi (Litchi chinensis) cultivars from India and effect of radiation processing. Radiat. Phys. Chem., 2010, 79, 994-1004.

2. Souza, M., Singh, R., Reddy, P., Hukkeri, V. and Byahatti, V., Hepatoprotective activity of fruit pulp extract of Litchi chinensis Sonner on carbon tetrachloride-induced hepatotoxicity in albino rats. Int. J. Alt. Med., 2006, 4, 1-5.

3. Irene, P. R., Babu, D. J., Rao, N. V. and Sheikh, R. A., Nootropic activity of fruit extracts of Litchi chinensis Sonn (Sapindaceae). Int. J. Pharm. Tech., 2012, 4, 4795-4804.

4. Kilari, E. and Putta, S., Biological and phytopharmacological descriptions of Litchi chinensis. Phcog. Rev., 2016, 10, 60-65.

5. Yewale, V., Misery of mystery of Muzaffarpur. Indian Pediatr., 2014, 51, 605-606.

6. Narain, J. P., Dhariwal, A. C. and MacIntyre, C. R., Acute encephalitis in India: an unfolding tragedy. Indian J. Med. Res., 2017, 145, 584-587.

7. Joshi, R., Kalantri, S. P., Reingold, A. and Colford Jr, J. M., Changing landscape of acute encephalitis syndrome in India: a systematic review. Natl. Med. J. India, 2012, 25, 212-220.

8. Dinesh, D. S. et al., Possible factors causing acute encephalitis syndrome outbreak in Bihar, India. Int. J. Curr. Microbiol. Appl. Sci., 2013, 2, 531-538.

9. Paireau, J., Tuan, N. H., Lefrancois, R., Buckwalterm, M. R. and Nghia, N. D., Litchi-associated acute encephalitis in children, Northern Vietnam, 2004-2009. Emerg. Infect. Dis., 2012, 18, $817-824$.

10. Bandyopadhyay, B., Chakraborty, D., Ghosh, S., Mishra, R. and Rahman, M., Epidemiological investigation of an outbreak of acute encephalitis syndrome (AES) in Malda district of West Bengal, India. Clin. Microbiol., 2015, 4, 181; doi:10.4172/23273635073.1000181.

11. Islam, M. S. et al., Outbreak of sudden death with acute encephalitis syndrome among children associated with exposure to lychee orchards in northern Bangladesh. Am. J. Trop. Med. Hyg., 2017, 97, 949-957.

12. John, T. J. and Das, M., Acute encephalitis syndrome in children in Muzaffarpur: hypothesis of toxic origin. Curr. Sci., 2014, 106, 184-185.

13. Shrivastava, A. et al., Association of acute toxic encephalopathy with litchi consumption in an outbreak in Muzaffarpur, India, 2014: a case-control study. Lancet Glob. Health, 2017, 5, 458-466.

14. Sherratt, H. S. A., Hypoglycin, the famous toxin of the unripe Jamaican ackee fruit. Trend. Pharm. Sci., 1986, 7, 375.

15. Gaillard, Y., Carlier, J., Berscht, M., Mazoyer, C., Bevalot, F., Guitton, J. and Fanton, L., Fatal intoxication due to ackee (Blighia sapida) in Suriname and French Guyana. GC-MS detection and quantification of hypoglycin-A. Forensic Sci. Int., 2011, 206, 103-107.

16. Melde, K., Buttener, H., Boschert, W., Wolf, H. P. and Ghisla, S., Mechanism of hypoglycaemic action of methylenecyclopropylglycine. Biochem. J., 1989, 259, 921-924.

17. Osmundsen, H., Billington, D., Taylor, J. R. and Sherratt, H. S., The effects of hypoglycin on glucose metabolism in the rat. Biochem. J., 1978, 170, 337-342. 
18. Feng, P. C. and Patrick, S. J., Studies of the action of hypoglycinA, an hypoglycaemic substance. Br. J. Pharmacol., 1958, 13, $125-130$.

19. Emanuel, M. A. and Benkeblia, N., Processing of ackee fruit (Blighia sapida $\mathrm{L}$.): present and future perspectives. Acta Hortic., 2011, 894, 211-213.

20. Chang, A., Orth, A., Le, B., Menchavez, P. and Miller, L., Performance analysis of the onetouch ${ }^{\circledR}$ UltraVue $^{\mathrm{TM}}$ blood glucose monitoring system. J. Diabetes Sci. Technol., 2009, 3, 1158 1165.

21. Garber, C. C., Jendrassik-Grof analysis for total and direct bilirubin in serum with a centrifugal analyser. Clin. Chem., 1981, 27, $1410-1416$.

22. Reitman, S. and Frankel, S. A., Colorimetric method for the determination of serum glutamic oxalacetic and glutamic pyruvic transaminases. Am. J. Clin. Pathol., 1957, 28, 56-63.

23. Bessey, O. A., Lowry, O. H. and Brock, M. J., A method for the rapid determination of alkaline phosphatase with five cubic millimeters of serum. J. Biol. Chem., 1946, 164, 321-329.

24. Toora, B. D. and Rajagopal, G., Measurement of creatinine by Jaffe's reaction-determination of concentration of sodium hydroxide required for maximum color development in standard, urine and protein free filtrate of serum. Indian J. Exp. Biol., 2002, 40, 352-354.

25. Jung, D., Biggs, H., Erikson, J. and Ledyard, P. U., New colorimetric reaction for end-point, continuous-flow, and kinetic measurement of urea. Clin. Chem., 1975, 21, 1136-1140.

26. Connerty, H. V. and Briggs, A. R., Determination of serum calcium by means of orthocresolphthalein complexone. Am. $J$. Clin. Pathol., 1966, 45, 290-296.

27. Taussky, H. H. and Shorr, E. A., Microcolorimetric method for the determination of inorganic phosphorus. J. Biol. Chem., 1953, 202, $675-685$.
28. Ibrahim S. R. M. and Mohamed, G. A., Litchi chinensis: medicinal uses, phytochemistry, and pharmacology. J. Ethnopharm., 2015, 174, 492-513.

29. Arika, W. M., Nayamai, D. W., Osano, K. O., Ngugi, M. P. and Njagi, E. N. M., Biochemical markers of in vivo hepatotoxicity. J. Clin. Toxicol., 2016, 6, 297; doi:10.4172/2161-0495.1000297.

30. Basu, S., Haldar, N., Bhattacharya, S., Biswas, S. and Biswas, M., Hepatoprotective activity of Litchi chinensis leaves against paracetamol-induced liver damage in rats. Am. Eur. J. Sci. Res., 2012, 7, 77-81.

31. Chen, L., Chang, C., Tsay, J. and Weng, B. B., Hepatoprotective effects of litchi (Litchi chinensis) procyanidin A2 on carbon tetrachloride-induced liver injury in ICR mice. Exp. Ther. Med., 2017, 13, 2839-2847.

32. Adamu, S. M., Wudil, A. M., Alhassan, A. J., Koki, Y. A. and Adamu, S., A review on biomarkers of kidney dysfunction in orthopaedic cases. IOSR J. Dental Med. Sci., 2016, 15, 88-98.

33. Nair, A. B. and Jacob, S., A simple practice guide for dose conversion between animals and human. J. Basic Clin. Pharm., 2016, 7, 27-31.

ACKNOWLEDGEMENT. We thank Dr Vishal Nath, Director, ICAR-National Research Centre of Litchi, Muzaffarpur, India for providing farm fresh samples for this study. The sole funding agency is the Government of India and no external source of fund or study sponsor is involved.

Received 8 April 2019; revised accepted 10 July 2019

doi: $10.18520 / \mathrm{cs} / \mathrm{v} 117 / \mathrm{i} 8 / 1292-1299$ 